\title{
De grote uitdagingen het sociaal werk
}

Door Jean Pierre Wilken

\author{
Wat zijn de grote maatschappelijke vraagstukken van onze tijd? \\ En wat kan sociaal werk bijdragen aan de oplossing ervan? In \\ de Verenigde Staten startte in 2016 een tienjarig project rond \\ die vragen onder de titel 'Grand Challenges for Social Work \\ and Society'. Jean Pierre Wilken stelt voor om in Nederland iets \\ vergelijkbaars te doen.
}

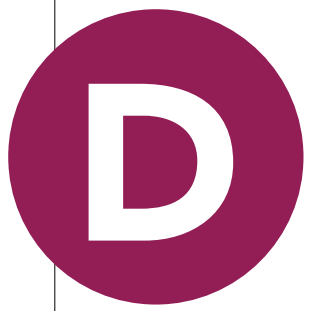

De internationale definitie van sociaal werk (IFSW \& IASSW, 2014) staat vol met grote woorden. Er wordt gesproken over sociale verandering, mensenrechten, sociale rechtvaardigheid, empowerment, en zelfs 'de bevrijding van mensen'. Het zegt iets over de stevige ambities van sociaal werk bij te willen dragen aan een betere samenleving. Op zich zijn dit levensgrote uitdagingen, die echter voor de meeste sociale professionals ver van hun dagelijks werk staan. Zij houden zich bezig met de ondersteuning van mensen die kampen met psychische, sociale of materiële problemen of zetten zich in voor de leefbaarheid van buurten en wijken. Hoe verhoudt dit zich tot de grote maatschappelijke vraagstukken waarvoor de samenleving zich gesteld weet? In de Verenigde Staten wordt de beantwoording van die vraag groots aangepakt. Daar werd in 2016 een landelijk tienjarig project gestart onder de titel 'Grand Challenges for Social Work and Society'. Is een dergelijke aanpak ook voor Nederland bruikbaar? En wat zijn eigenlijk de grote uitdagingen in Nederland?

\section{Meeslepend}

Het initiatief tot bovengenoemd project in de VS werd genomen door

\section{Oorspronkelijk}

\section{kwamen ruim}

\section{tachtig vraagstukken}

\section{op tafel}

de American Academy of Social Work and Social Welfare (AASWSW), een vereniging van vooraanstaande wetenschappers en professionals in het sociaal domein. Gedurende twee jaar bogen onderzoekers, professionals, studenten en burgers zich in allerlei netwerken en werkgroepen over de sociale vraagstukken in het land. Zij deden onderzoek naar en dachten na over de belangrijkste uitdagingen or de Amerikaanse samenleving en de bijdrage kaart te brengen uitdagingen moesten voldoen. Die uidden als volgt: (1) Een uitdaging moet groot, grijk en meeslepend zijn, (2) wetenschappelijk bewijs laat zien dat de uitdaging oplosbaar is,

mogelijk zijn om in tien jaar zinvolle en meetbare vooruitgang te boeken, (4) de uitdaging moet met grote waarschijnlijkheid tot interdisciplinaire samenwerking leiden, en (5) de oplossing van de uitdaging vereist significante innovatie. In 2018 verscheen een boek met de resultaten van dit onderzoek: Grand Challenges for SocialWork and Society (Fong et al., 2018). Oorspronkelijk kwamen er meer dan tachtig vraagstukken op tafel. Uiteindelijk werden deze geprioriteerd tot twaalf grote uitdagingen, die de onderzoekers verdeelden over drie the- 


\begin{tabular}{|l|c|c|}
\hline Welzijn van individuen en families & Sterker sociaal weefsel & Rechtvaardige samenleving \\
\hline $\begin{array}{l}\text { Zorgen voor een gezonde ontwikkeling } \\
\text { van alle jeugdigen }\end{array}$ & $\begin{array}{c}\text { Doorbreken van sociaal } \\
\text { isolement }\end{array}$ & $\begin{array}{c}\text { Bevorderen van slimme } \\
\text { reïntegratie na internering }\end{array}$ \\
\hline Dichten van de gezondheidskloof & Beëindigen van dakloosheid & Financiële capaciteit voor iedereen \\
\hline Stoppen van huiselijk geweld & $\begin{array}{c}\text { Sociale antwoorden creëren } \\
\text { voor klimaatverandering }\end{array}$ & $\begin{array}{c}\text { Verminderen van extreme } \\
\text { economische ongelijkheid }\end{array}$ \\
\hline $\begin{array}{l}\text { Bevorderen van een lang en productief } \\
\text { leven }\end{array}$ & $\begin{array}{c}\text { Technologie inzetten voor } \\
\text { sociaal welzijn }\end{array}$ & $\begin{array}{c}\text { Bereiken van gelijke kansen en } \\
\text { rechtvaardigheid }\end{array}$ \\
\hline
\end{tabular}

Fig.1: De 'grand challenges' van het sociaal werk

ma's: het welzijn van individuen en families, een sterker sociaal weefsel en een rechtvaardige samenleving (zie fig. 1). Aan de twaalf uitdagingen werd recentelijk, mede onder invloed van de Black Lives Matter-beweging, nog een dertiende toegevoegd: het elimineren van racisme.

Een uitdaging als reïntegratie van gedetineerden is in de VS een 'grand challenge', omdat het land mondiaal relatief gezien de grootste populatie ter wereld achter de tralies en een falend reclasseringssysteem heeft. Uiteraard hangt dit samen met andere problemen: hoge criminaliteitscijfers, vaak gerelateerd aan armoede, drugsverslaving en wapenbezit en het slechte functioneren van het politieapparaat. In Nederland zouden we dit niet als een grote uitdaging beschouwen. Ook sociaaleconomische gezondheidsverschillen zijn in Nederland veel kleiner dan in de VS. Niettemin zijn de meeste vraagstukken voor ons zeer herkenbaar.

\section{Belang van onderzoek}

Het proces in de Verenigde Staten om tot de "grand challenges' te komen is interessant omdat het de banden tussen sociaal werkorganisaties, onderzoeksinstituten en opleidingen verstevigd heeft. Alleen daarom al kon je spreken van innovatie. Bovendien leidde de exposure van het project tot een hoger aanzien van sociaal werk als professionele discipline en als wetenschap. Ten slotte maakte het identificeren van de 'grand challenges' het mogelijk een sociale agenda voor Amerika op te stellen, waarmee de politiek te voeden was. Opvallend is ook dat onderzoek een belangrijke rol speelde. Het werd niet alleen ingezet om de uitdagingen, zowel kwantitatief als kwalitatief, goed te beschrijven, maar ook om in kaart te brengen welke (potentiële) oplossingen al ontwikkeld en onderzocht waren. Ook de in gang gezette innovaties (nieuwe oplossingen ontwerpen en uittesten) en de implementatie van bestaande kennis ging altijd samen met onderzoek. Onderzoek zorgde en zorgt voor bewijskracht. In de netwerken rond de uitdagingen participeerden wetenschappers, beroepsverenigingen van sociaal werkers en cliëntenorganisaties. Ook studenten werden nadrukkelijk uitgenodigd mee te doen en zich al tijdens hun studie te verdiepen in de 'grand challenges'. Bij het uitwerken van de vraagstukken waren dus vele partijen betrokken. Hoewel wetenschappelijke kennis een belangrijke basis vormde, moest het initiatief doorwerking hebben naar de praktijk, het beleid en de opleidingen.

\section{Leerpunten}

Nadat de grote uitdagingen vastgesteld waren, werd in 2016 een tienjarenprogramma gestart. Vorig jaar verscheen een evaluatierapport met daarin de opbrengsten van de eerste vijf jaar. Het valt op dat er vooral veel lobbywerk is verricht en dat er betrekkelijk weinig concrete innovaties zijn gerealiseerd. Met Amerikaans optimisme echter wordt gesteld: 'The best is yet to come'. En ook in Amerika gooide Covid-19 roet in het eten. Wel vond in de verschillende netwerken veel kennisuitwisseling plaats, zijn er studies uitgevoerd, publicaties en podcasts uitgebracht en waren er conferenties en webinars. Al met al is er veel in gang gezet en de grote thema's werken in ieder geval stimulerend en verbindend.

Samenvattend kunnen we het volgende leren van de Amerikaanse aanpak: (1) Het formuleren van de meest urgente maatschappelijke vraagstukken vestigt de aandacht op wat werkelijk belangrijk is. Het richt de aandacht op wat 'de bedoeling' is, namelijk het werken aan fundamentele misstanden die bestaanskwaliteit in de weg zitten. Dit overstijgt de politieke waan van de dag, al komt politiek natuurlijk onmiddellijk om de hoek kijken als het gaat om implementatie. (2) Grote vraagstukken leidend laten zijn voor onderzoek, ontwikkeling, opleiding, praktijk en beleid werkt verbindend en enthousiasmerend. (3) De sociale agenda is goed te verbinden met investeringen die nodig zijn voor onderzoek, ontwikkeling en implementatie. Vergeleken met een losse projectcarrousel maakt zo'n agenda het mogelijk veel programmatischer te werken. Een periode van tien jaar lijkt hierbij goed gekozen. 


\section{Vier pijlers}

Ook in Nederland werd vorig jaar het initiatief genomen om, aan de hand van een inventarisatie van maatschappelijke vraagstukken, tot een landelijke kennis- en onderzoeksagenda sociaal werk te komen (Hooghiemstra en Van Pelt, 2020). Doel van het initiatief was nadrukkelijk om de positie van sociaal werkers te versterken. Een criterium voor opname in de agenda was dan ook dat sociaal werk bij het oplossen van de te agenderen vraagstukken onmisbaar zou zijn. Er werden vier 'pijlers' geformuleerd voor de agenda: (1) versterken van sociale samenhang, (2) bevorderen van inclusie, (3) centraal stellen van het gewone leven en (4) door laten klinken van de stem van de burger. Aan deze thema's werden vervolgens kennisvraagstukken gekoppeld die vrij algemeen van aard zijn, zoals 'individu versus systeem', 'moreel afwegingskader', 'relationele inbedding', 'netwerkgericht werken' en 'methodisch werken aan versterken van invloed, inspraak en medezeggenschap'. In vergelijking met de Amerikaanse agenda valt op dat het thema's zijn die weinig urgentie uitstralen. Het is meer een professionaliseringsagenda dan een sociale (actie)agenda. Dat is echter inherent aan de wijze waarop de agenda tot stand is gekomen, namelijk door de praktijkvragen en de kennis van professionals als uitgangspunt te nemen. Er wordt echter wel degelijk een aantal urgente vraagstukken genoemd, zoals polarisatie, radicalisering en ondermijning, leefbaarheid en veiligheid in buurten, sociaal isolement, armoede en schulden, en situaties waarin sprake is van een opeenstapeling van problemen.

\section{Een voorstel}

We zouden dit rijtje als uitgangspunt kunnen nemen bij de vaststelling van de grote maatschappelijke vraagstukken en uitdagingen waarvoor Nederland zich anno 2022 geplaatst ziet. Mijn voorstel is om, voortbouwend op het initiatief van de landelijke kennis- en onderzoeksagenda sociaal werk en met inbreng van alle partijen die zich hieraan verbonden hebben, de grote uitdagingen voor ons land te onderzoeken en beschrijven, goed onderbouwd met kwantitatieve en kwalitatieve data. Dit zou bijvoorbeeld kunnen resulteren in een aantal 'state of the art'- papers, zoals onlangs voorgesteld door de Wetenschappelijke Adviesraad Onderzoek Sociaal Werk. Het is alleszins waarschijnlijk dat diverse thema's die in de VS spelen, ook in ons land hoog op de agenda komen. Ik noem bijvoorbeeld eenzaamheid en sociaal isolement (35\% van de bevolking), huiselijk geweld ( $8 \%$ van de bevolking), en sociaaleconomische ongelijkheid ( $8 \%$ van de bevolking onder de lage-inkomensgrens). Maar ook de polarisatie in de samenleving en de bedreigingen van ons fysieke leefklimaat vragen veel aandacht. Een volgende stap is dan om een landelijk actieplan te maken aan de hand waarvan we tien jaar gaan werken aan innovatieve oplossingen (met na vijf jaar een tussenevaluatie).

\section{Ten slotte}

Over belangrijke maatschappelijke vraagstukken is al veel kennis beschikbaar bij landelijke kennisinstituten, hogescholen en universiteiten. We kunnen deze kennis niet alleen gebruiken om de grootste uitdagingen te bepalen en goed te beschrijven, maar ook om zicht te krijgen op de kennis die er al is over oplossingen. In het actieplan gaat het om concrete, implementeerbare innovaties. Die kunnen betrekking hebben op microniveau (werken met inwoners), mesoniveau (organisatie en lokaal bestuur en beleid) en macroniveau (landelijk bestuur en beleid). Omdat deze niveaus bij grote uitdagingen altijd met elkaar verbonden zijn, dienen we onze oplossingsstrategieën ook integraal te benaderen en op alle drie niveaus uit te werken (Wilken e.a., 2021). In het plan kunnen we beschrijven wat de inzet is en zou moeten zijn vanuit het werkveld (professionals en inwoners), de overheid, onderzoek en opleidingen. Met deze beweging, verwacht ik, kunnen we de impact en waarde van sociaal werk aantonen én versterken. De vraag is nu: durven we de uitdaging aan?

\section{Jean Pierre Wilken geeft leiding aan het Lectoraat Participatie Zorg en Ondersteuning, dat onderdeel is van het Kenniscentrum Sociale Innovatie van Hogeschool Utrecht. Daarnaast is hij gasthoogleraar aan de universiteiten van Tallinn (Estland) en Milaan (Italië).}

\section{Bronnen}

- view.pagetiger.com/grand-challenges-impact-report-2021

- longreads.cbs.nl/nederland-in-cijfers-2020/hoe-eenzaamvoelen-we-ons/

- longreads.cbs.nl/impactmonitorhgkm-2020/aanpakhuiselijk-geweld-en-kindermishandeling-in-cijfers/

- cbs.nl/nl-nl/cijfers/detail/83841NED;

- longreads.cbs.nl/welvaartinnederland-2019/ongelijkheid-in-inkomen-en-vermogen/

- Fong, R., Lubben, J. \& Barth, R.P. eds (2018). Grand Challenges for Social Work and Society. Oxford University Press

- Hooghiemstra, E. \& Van Pelt, M. (2020). De Kennis- en Onderzoeksagenda Sociaal Werk. Utrecht: Movisie

- Wilken, J.P., Overkamp, E., Binkhorst, J. \& Sprinkhuizen, A. (2021). Integraal werken en sociaal werk: vier perspectieven op een weerbarstige werkelijkheid. In: Metz, J., JagerVreugdenhil, M., Wilken, J.P. \& Witte, T. (2021). Sociaal Werk Doordacht. Amsterdam: SWP, pp. 53-66 